\title{
Effectiveness of different fungicide formulations and number of applications in controlling wheat leaf rust
}

\author{
Jhonatan Paulo Barro'; Cesar Tiago Forte ${ }^{2}$; Diego Trentin ${ }^{3}$; Maurício Scariot ${ }^{4}$; Paola Mendes Milanesi ${ }^{5}$
}

\begin{abstract}
${ }^{1}$ Mestrando no programa de Pós Graduação em Fitopatologia da Universidade Federal de Viçosa. Viçosa, MG, Brasil; ${ }^{2}$ Doutorando no programa de Pós Graduação em Agronomia da Universidade Federal de Santa Maria. Santa Maria, RS, Brasil; ${ }^{3}$ Bacharel em Agronomia, Erechim, RS, Brasil; ${ }^{4}$ Doutorando no programa de Pós Graduação em Fitotecnia da Universidade Federal do Rio Grande do Sul. Porto Alegre, RS, Brasil; ${ }^{5}$ Professora Adjunta de Fitopatologia da Universidade Federal da Fronteira Sul, Erechim, RS, Brasil.
\end{abstract}

Autor para correspondência: Jhonatan Paulo Barro ( jhonatanbarro@gmail.com)

Data de chegada: 14/01/2017. Aceito para publicação em: 18/04/2017.

$10.1590 / 0100-5405 / 174240$

\section{ABSTRACT}

Barro, J.P.; Forte, C.T.; Trentin, D.; Scariot, M.; Milanesi, P.M. Effectiveness of different fungicide formulations and number of applications in controlling wheat leaf rust. Summa Phytopathologica, v.43, n.4, p.276-280, 2017.

Leaf rust (Puccinia triticina) is one of the most common diseases in wheat crops. For effective control of such disease, leaf application of mixtures of triazole and strobilurin fungicides is recommended. The aim of this study was to evaluate the efficacy of different fungicide formulations and numbers of applications in controlling wheat leaf rust in the cultivar TBIO Pioneiro 2010. Experimental design was completely randomized, $2 \times 2$ factorial arrangement, consisting of two fungicide formulations and two numbers of applications, as well as four replicates. Treatments were: azoxystrobin + tebuconazole, three and four applications; trifloxystrobin + prothioconazole, three and four applications; and a control treatment without fungicide application. For treatments with three applications, fungicides were applied at the phenological stages of: elongation, booting and flowering. For treatments with four applications, fungicides were applied at the phenological stages of: tillering, elongation, booting and flowering. The efficiency of fungicides on leaf rust control was analyzed based on the disease severity assessment by calculating the Area Under Disease Progress Curve (AUDPC). Severity data were obtained based on percentage scores of leaf area with visible disease symptoms/signs according to Cobb's diagrammatic scale. Fungicides with azoxystrobin + tebuconazole and trifloxystrobin + prothioconazole showed efficient control of wheat leaf rust (higher than $85 \%$ ). For yield components, there was no statistical difference between numbers of applications, but there was a statistical difference between fungicide formulations, except for grain yield. Furthermore, for yield components, all fungicide treatments significantly differed from control.

Keywords: Puccinia triticina, AUDPC, chemical control, strobilurins, triazoles.

\section{RESUMO}

Barro, J.P.; Forte, C.T.; Trentin, D.; Scariot, M.; Milanesi, P.M. Eficácia de diferentes formulações fungicidas e número de aplicações para o controle da ferrugem da folha no trigo. Summa Phytopathologica, v.43, n.4, p.276-280, 2017.

A ferrugem da folha do trigo (Puccinia triticina) é uma das doenças mais frequentes em lavouras de trigo. Para um controle efetivo dessa doença é recomendado o controle foliar através da aplicação de misturas de fungicidas triazóis e estrobilurinas. O objetivo deste estudo foi avaliar a eficácia das diferentes formulações fungicidas e do número de aplicações para o controle da ferrugem da folha do trigo na cultivar TBIO Pioneiro 2010. O delineamento experimental utilizado foi inteiramente casualizado, fatorial $2 \times 2$, consistindo em duas formulações fungicidas e dois números de aplicações, com quatro repetições. Os tratamentos foram: azoxistrobina + tebuconazol com três e quatro aplicações; trifloxistrobina + protioconazol com três e quatro aplicações; e um tratamento testemunha sem aplicação de fungicida. Nos tratamentos com três aplicações, os fungicidas foram aplicados nos estádios fenológicos de: alongamento, emborrachamento e florescimento. Os tratamentos com quatro aplicações foram realizados nos estádios fenológicos de: perfilhamento, alongamento, emborrachamento e florescimento. A eficiência dos fungicidas no controle da ferrugem foi analisada através da avaliação da severidade da doença, calculando-se a Área Abaixo da Curva de Progresso da Doença (AACPD). Os dados de severidade foram obtidos através de notas da porcentagem da área foliar com sintomas/sinais da doença segundo a escala diagramática de Cobb. Fungicidas com azoxistrobina + tebuconazol e trifloxistrobina + protioconazol apresentaram eficiência no controle de ferrugem da folha de trigo (todos acima de $85 \%$ ). Em componentes de rendimento, não houve diferença estatística entre o número de aplicações, mas, houve diferença estatística entre as formulações de fungicidas, exceto para produtividade. Além disso, para os componentes do rendimento, todos os tratamentos fungicidas diferiram significativamente da testemunha.

Palavras-chave:Puccinia triticina, AACPD, controle químico, estrobilurinas, triazóis

Wheat (Triticum aestivum L.) is an annual grass crop grown during the winter. This crop is important in the composition of sustainable agricultural production systems as an alternative to winter rotation in production systems, contributing to integrated management of pests, diseases and weeds. In addition, this crop has great importance in the diet because of its quality and quantity of protein (De Mori (11)). Flour is the major form of wheat consumption and is widely used in the human diet as bread, pasta, biscuits and other food. It is also used in animal diet as hay, grain or bran in the feed composition.

Several factors can reduce wheat yield, including losses due to diseases. For susceptible cultivars, chemical control through fungicide application has been the strategy most widely used by producers since it has offered security to farmers when applied early in the appearance of the first symptoms. 
Wheat leaf rust (Puccinia triticina Ericks.) is one of the most common diseases found in wheat crops. This disease is characterized by the appearance of pustules with yellow-dark to brown spores in the uredia, from seedling emergence to the maturity stage. Temperature range for the disease development is between 15 and $20^{\circ} \mathrm{C}$ under high humidity, and the fungus requires at least three hours of continuous wetness to infect the host plant (Embrapa (13)). It should be emphasized that the causal agent of wheat leaf rust is a biotrophic parasite, i.e. in the absence of wheat, the pathogen survives only in volunteer plants present in the fields, roadsides and highways (Reis \& Casa (16)).

For effective disease control, resistant cultivars are recommended. Another form of control is through the reduction of primary inoculum, eliminating volunteer plants at the beginning of their development (Embrapa (13)). As to chemical control, leaf treatment is preferred by means of application of mixtures of triazole and strobilurin fungicides at recommended doses (Reis et al. (17)). Combination of these strategies or integration of cultural and genetic control, as well as the use of fungicides, would be the most effective ways to control this disease (Xue et al. (18)).

The aim of this study was to evaluate the effectiveness of two fungicide formulations and two numbers of applications in controlling wheat leaf rust.

\section{MATERIAL AND METHODS}

This study was conducted in the experimental area of Federal University of Fronteira Sul, Erechim Campus, in the 2015 growing season. Local climate is Cfa according to Koppen's classification, and rainfall is well distributed throughout the year. The soil is classified as Oxisol Alumino Humic (Embrapa (14)) and has medium organic matter content $(3.7 \%)$. The area where the experiment was installed was in winter fallow for five seasons.

Experimental design was completely randomized, $2 \times 2$ factorial arrangement, consisting of two fungicide formulations and two numbers of application, with four replicates. Each experimental unit consisted of a plot, $3 \mathrm{~m}$ wide and $4 \mathrm{~m}$ long, totaling $12 \mathrm{~m}^{2}$. Treatments are described in Table 1.

Before sowing, an application of glyphosate herbicide was performed to control weeds existing in the area. TBIO Pioneiro 2010 wheat cultivar was used in this study; it is considered moderately resistant to wheat leaf rust (Biotrigo (4)). Seeds were treated with imidacloprid (penetrant mobile insecticide) + thiodicarb (contact and ingestion insecticide) and carboxin + thiram (penetrant mobile and non-penetrant fungicide). Sowing was performed on 06/25/2015 at $17 \mathrm{~cm}$-spaced rows and plant density of $250 / \mathrm{m}^{2}$ (Biotrigo (4)).

At sowing, the crop was fertilized with formula 05-30-15 (NPK) at the rate of $160 \mathrm{~kg} / \mathrm{ha}$. In addition, cover fertilization was made with
$150 \mathrm{~kg} /$ ha nitrogen as urea $(45 \% \mathrm{~N})$, divided into two parts: $40 \%$ at early tillering and $60 \%$ at flowering beginning.

Regarding the number of fungicide applications, there were treatments with four applications, at tillering (preventive), elongation, booting and flowering, and there were treatments with three applications, at elongation, booting and flowering stages. The fungicides azoxystrobin + tebuconazole and trifloxystrobin + prothioconazole were applied at $0.5 \mathrm{~L} / \mathrm{ha}$, considering $150 \mathrm{~L} /$ ha spray volume. Furthermore, for better fungicide effectiveness, the adjuvant Aureo ${ }^{\circledR}$ was added at the recommended dose of $0.5 \mathrm{~L} / \mathrm{ha}$. Fungicides were applied with a manual precision sprayer under constant $\mathrm{CO}_{2}$ pressure.

Leaf rust severity data were obtained based on percentage scores of leaf area with symptoms/signs. Fully formed pustules were considered those with abundant sporulation. Following the appearance of the first symptoms, five infected wheat leaves were sampled from each plot, at weekly interval, up to kernel hard dough stage. Then, these leaves were scanned and compared according to diagrammatic Cobb's scale (Peterson et al. (15)).

To determine the Area Under Disease Progress Curve (AUDPC), severity percentages obtained in each evaluation were used. The AUDPC values were calculated according to the equation proposed by Campbell \& Madden (6) (Equation 1):

$$
A A C P D=\sum\left\{\left[\frac{\left(Y_{i}+Y_{i+1}\right)}{2}\right] x\left(t_{i+1}-t_{i}\right)\right\}
$$

where:

$\mathrm{Y}_{\mathrm{i}}$ and $\mathrm{Y}_{\mathrm{i}+1}$ are the values of two consecutive severity assessments, and $t_{i}$ and $t_{i+1}$ are the dates of the two assessments

Harvest was done by hand cutting the plants in a $3 \mathrm{~m}^{2}$ area. After harvest, grain moisture, hectoliter weight $(\mathrm{HW})$, total yield $\left(\mathrm{kg} / \mathrm{ha}^{\mathrm{l}}\right)$ and thousand grain weight $(\mathrm{g})$ were determined. Moisture was determined by adopting the oven method at $105^{\circ} \mathrm{C}$; HW was determined by using a hectoliter scale of $250 \mathrm{~mL}$ capacity; the weight values obtained for the plots were extrapolated to yield per hectare, and thousand grain weight was also determined according to the Rules for Seed Analysis (Brasil (5)).

Data were subjected to analysis of variance according to $\mathrm{F}$ test at $5 \%$ probability, and means were compared according to Tukey's test at $5 \%$ probability. Similarly, treatments were compared with control according to Dunnett's test at 5\% probability. Statistical analysis was performed by using ASSISTAT 7.6 beta software.

\section{RESULTS AND DISCUSSION}

Wheat leaf rust severity (\%), according to the evaluation time (days), is found in Figure 1.

Table 1. Treatments according to fungicide formulations (active ingredients) and number of applications for wheat leaf rust control. Erechim, RS. 2015

\begin{tabular}{llcc}
\hline Treatments & & a. i. $^{\mathbf{1}} \mathbf{g ~ h \mathbf { ~ h } ^ { - 1 }}$ & C. $^{\mathbf{2}} \mathbf{L ~ h a}^{\mathbf{1}}$ \\
\hline T1 & Azoxystrobin + tebuconazole - 3 applications & $60+100$ \\
T2 & Azoxystrobin + tebuconazole - 4 applications & $60+100$ \\
T3 & Trifloxystrobin + prothioconazole - 3 applications & $150+175$ \\
T4 & Trifloxystrobin + prothioconazole - 4 applications & $150+175$ \\
T5 & Control - no application & 0.5 & 0.5 \\
\hline
\end{tabular}

${ }^{1}$ a. i.: dose of active ingredient $\mathrm{g} / \mathrm{ha} ;{ }^{2}$ C. P.: dose of the commercial product in $\mathrm{L} / \mathrm{ha}$. 


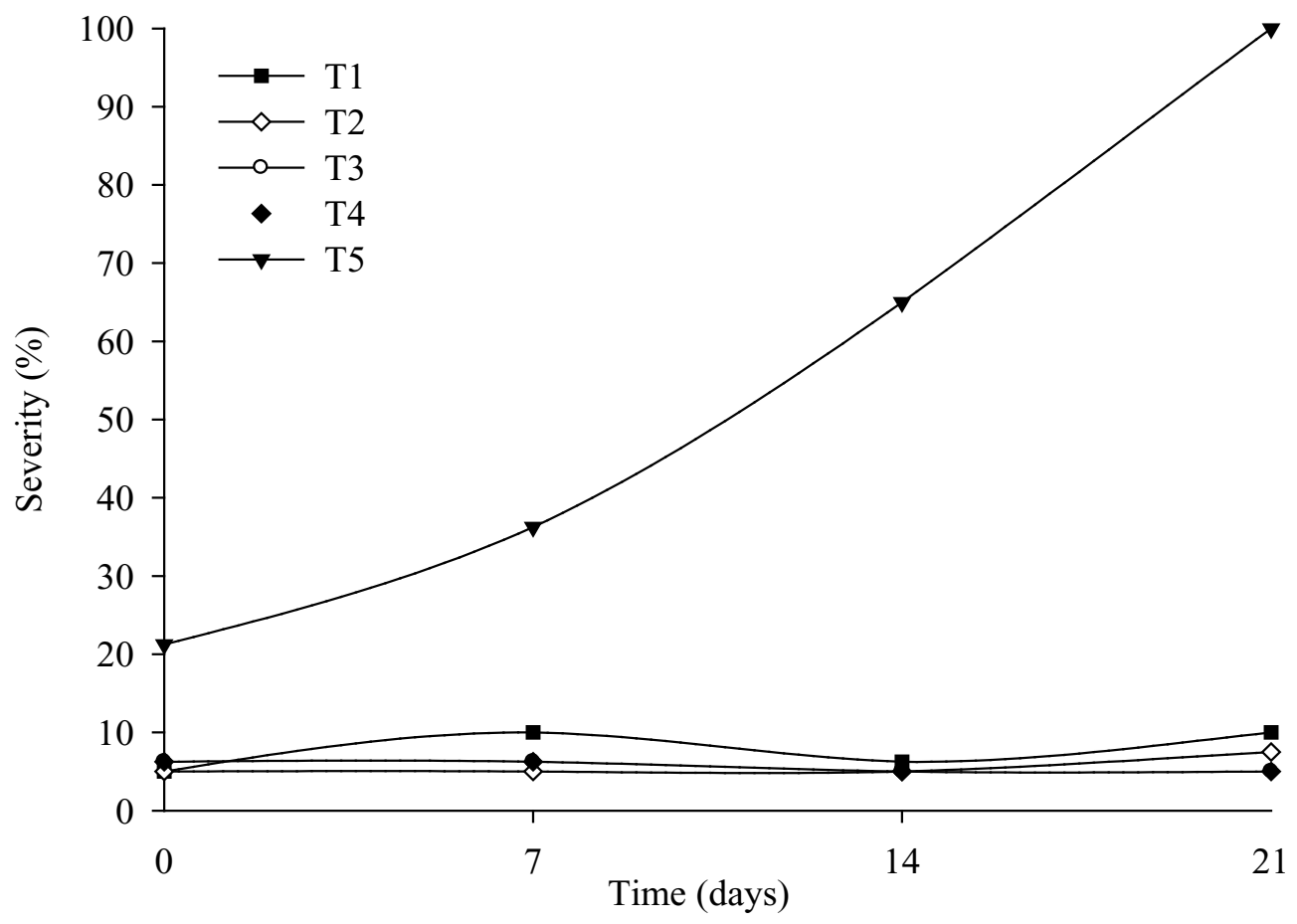

Figure 1. Severity (\%) of wheat leaf rust (Puccinia triticina) observed in leaf samples collected after treatments with different fungicide formulations and numbers of applications at seven-day intervals.

During the 21 days of evaluation, the disease progression in the control treatment (T5) reached $100 \%$ severity. For T3 and T4, the severity value was the same (5.6\%); thus, their lines were superposed, showing no difference between the numbers of applications. T1 and T2 showed similar performance, but the severity value in $\mathrm{T} 1$ was relatively higher (7.8\%), compared to T2 (5.6\%), which could be justified since the preventive application in T2 (four applications) helped control the disease.

The results obtained in the severity analysis were used to calculate the daily increase (Table 2).

As shown in Table 2, for the sampling interval between 7 and 14 days, there was no daily increase in the disease severity for T1, T3, T4 and T2. This may be explained due to a fungicide application exactly in this interval, reducing the disease severity. Control treatment had a progressive increase in disease severity due to the absence of fungicide treatment.

Results of AUDPC and percentage of control are shown in Table 3.

The tested fungicide formulations showed a good control of wheat leaf rust, all above $85 \%$. The use of mixtures formulated with strobilurins and triazoles proved to be more efficient than the same compounds applied alone to control wheat leaf rust. In a study by Assunção \& Torres (2), a mixture with strobilurin (trifloxystrobin) and triazole (tebuconazole) was more efficient than the same compounds applied alone. Rust control was $96.4 \%$ for the formulated mixture (trifloxystrobin + tebuconazole), $90.4 \%$ for treatment with tebuconazole and $86.4 \%$ for treatment with trifloxystrobin.

Correa et al. (8) also reported fungicide efficiency in controlling wheat leaf rust. Treatments that showed better results were azoxystrobin + cyproconazole, pyraclostrobin + epoxiconazole and trifloxystrobin + tebuconazole. These formulations showed control above $80 \%$, especially the formulated mixture pyraclostrobin + epoxiconazole, which had $86.6 \%$ efficiency.

It is important to emphasize the low control effectiveness, especially
Table 2. Daily increase (\%) in wheat leaf rust severity (Puccinia triticina) after treatments with different fungicides and numbers of applications, at seven-day intervals. Erechim, RS. 2015

\begin{tabular}{lccc}
\hline Treatments & $\begin{array}{c}\text { Time } \\
\text { (days) }\end{array}$ & $\begin{array}{c}\text { Severity } \\
(\%)\end{array}$ & $\begin{array}{c}\text { Daily severity } \\
\text { increase }(\%)\end{array}$ \\
\hline T1 - Azoxystrobin & 0 & 5.00 & --- \\
+ tebuconazole - 3 & 7 & 10 & 0.71 \\
applications & 14 & 6.25 & -0.53 \\
\hline T2 - Azoxystrobin & 21 & 10 & 0.53 \\
+ tebuconazole - 4 & 0 & 5.00 & --- \\
applications & 7 & 5.00 & 0 \\
\hline T3 - Trifloxystrobin & 14 & 5.00 & 0 \\
+ prothioconazole - 3 & 21 & 7.50 & 0.35 \\
applications & 0 & 6.25 & --- \\
\hline & 14 & 6.25 & 0 \\
T4 - Trifloxystrobin & 21 & 5.00 & -0.18 \\
+ prothioconazole - 4 & 0 & 6.00 & 0 \\
applications & 7 & 6.25 & --- \\
\hline & 14 & 5.00 & 0 \\
& 21 & 5.00 & -0.18 \\
T5 - Control & 0 & 21.25 & 0 \\
\hline
\end{tabular}

by some triazoles like tebuconazole, which can be explained by the reduction in the sensitivity of the causal agent of leaf rust to the fungicide, as reported in some studies in the 2005 growing season (Arduim et al. (1)), recommending the mixture of triazoles with strobilurins for more effective leaf rust control. Furthermore, Barros et 
Table 3. Area Under Disease Progress Curve (AUDPC) and control percentage for the tested treatments. Erechim, RS, 2015

\begin{tabular}{lcc}
\hline \multicolumn{1}{c}{ Treatments } & AUDPC & Control (\%) \\
\hline T1 - Azoxystrobin + tebuconazole - 3 applications & 166.25 & 85.30 \\
T2 - Azoxystrobin + tebuconazole - 4 applications & 113.75 & 89.90 \\
T3 - Trifloxystrobin + prothioconazole - 3 applications & 118.12 & 89.50 \\
T4 - Trifloxystrobin + prothioconazole - 4 applications & 118.12 & 89.50 \\
T5 - No application & 1133.12 & 0 \\
\hline
\end{tabular}

Table 4. Yield Components (HW, Yield and thousand grain weight) after treatment with different fungicide formulations for wheat leaf rust control. Erechim, RS. 2015.

\begin{tabular}{|c|c|c|c|}
\hline Fungicide Formulations & $\begin{array}{c}\text { HW } \\
\left(\mathrm{kg} \mathrm{hL}^{-1}\right)\end{array}$ & $\begin{array}{c}\text { Yield } \\
\left(\mathrm{kg} \mathrm{ha}^{-1}\right)\end{array}$ & $\begin{array}{c}\text { Thousand Grain } \\
\text { Weight }\left(\mathrm{g}^{-1}\right)\end{array}$ \\
\hline Trifloxystrobin + prothioconazole & $76.60 \mathrm{a}$ & $1,684.45 \mathrm{a}$ & $29.90 \mathrm{a}$ \\
\hline $\mathrm{CV}(\%)$ & 1.78 & 10.93 & 3.86 \\
\hline
\end{tabular}

${ }^{*}$ Means followed by the same letter in the columns do not differ statistically according to Tukey's test $(\mathrm{p} \leq 0.05)$.

Table 5. Yield Components (HW, Yield and thousand grain weight) after treatment with different fungicide formulations and numbers of applications for wheat leaf rust control. Erechim, RS. 2015.

\begin{tabular}{|c|c|c|c|}
\hline Treatments & $\begin{array}{c}\text { HW } \\
\left(\mathrm{kg} \mathrm{hL}^{-1}\right)\end{array}$ & $\begin{array}{c}\text { Yield } \\
\left(\mathrm{kg} \mathrm{ha}^{-1}\right) \\
\end{array}$ & $\begin{array}{c}\text { Thousand Grain } \\
\text { Weight }\left(\mathrm{g}^{-1}\right)\end{array}$ \\
\hline T1 - Azoxystrobin + tebuconazole -3 applications & $74.80 *$ & $1,543.12 *$ & $28.70^{*}$ \\
\hline $\mathrm{T} 2$ - Azoxystrobin + tebuconazole -4 applications & $75.60^{*}$ & $1,684.45^{*}$ & $28.10^{*}$ \\
\hline $\mathrm{T} 3$ - Trifloxystrobin + prothioconazole -3 applications & $76.70^{*}$ & $1,593.93 *$ & $30.00 *$ \\
\hline T4 - Trifloxystrobin + prothioconazole -4 applications & $76.60^{*}$ & $1,681.40^{*}$ & $29.90^{*}$ \\
\hline T5 - Control & 69.20 & 851.91 & 21.60 \\
\hline
\end{tabular}

*Means are statistically different from control according to Dunnett's test $(\mathrm{p} \leq 0.05)$.

al. (3) noted that application of strobilurin fungicide group can prolong the period of healthy green leaf area maintenance in the crop and, consequently, may have a positive impact on the yield.

To determine yield components, it was evaluated HW $(\mathrm{kg} \mathrm{hL}$ $\left.{ }^{1}\right)$, grain yield $(\mathrm{kg} / \mathrm{ha})$ and thousand grain weight $(\mathrm{g})$. There was no statistical difference between the numbers of applications for any of the analyzed components. However, there was statistical difference between the tested fungicide formulations for HW and thousand grain weight, but not for grain yield (Table 4).

For HW and thousand grain weight, the fungicide formulation trifloxystrobin + prothioconazole differed significantly from azoxystrobin + tebuconazole. This fungicide formulation presents preventive and curative action, with unique combination of active ingredients, which is ideal for modes of action rotation.

Furthermore, for HW, yield and thousand grain weight, all fungicide treatments (T1, T2, T3 and T4) differed significantly from control (T5) (Table 5).

Weather conditions once again were not good for the wheat crop in 2015 season. Heavy rainfall at harvest time and occurrence of frost out of season affected productivity in Rio Grande do Sul State. As shown in Table 4, HW was below 78, a parameter which is related to wheat quality Type 1 (Embrapa Trigo (12)).

Thousand grain weight was also below average for this cultivar, which is $35 \mathrm{~g}$ (Biotrigo (4)). In addition, all fungicide formulations and numbers of applications were superior to control (Table 5).
Barros et al. (3) obtained the same results in a chemical control test, noting that the thousand grain weight was higher in plots treated with fungicides, thus showing the effect of chemical treatment in the thousand grain weight. According to Cunha \& Bonaldo (9), the increase in seed weight is not only a result of disease control, but also of greater transport of nutrients and increased maturation period provided by fungicides.

The yield obtained in this experiment was below yield average reported for the producing regions in the state of Rio Grande do Sul for the 2015 agricultural season, which was $1700 \mathrm{~kg} / \mathrm{ha}$ (Conab (7)).

Dallagnol et al. (10) reported that the influence of leaf diseases on wheat can reduce grain yield by up to $63.52 \%$ when the control of wheat leaf rust is not performed. It is important to emphasize that leaf diseases must be controlled to ensure high yields in wheat crop.

Fungicide formulations with azoxystrobin + tebuconazole and trifloxystrobin + prothioconazole have efficient control (all above $85 \%$ ) of wheat leaf rust.

As to the number of applications for leaf rust control, the fungicide formulation azoxystrobin + tebuconazole shows higher severity with three applications, compared to the treatment with four applications.

For yield components, there was no statistical difference between the numbers of applications, but there was statistical difference between fungicide formulations, except for yield. Also considering yield components, all fungicide treatments differed significantly from the control. 


\section{REFERENCES}

1. Arduim, F.S.; Reis, E.M.; Barcellos, A.L.; Turra, C. In vivo sensitivity reduction of Puccinia triticina races, causal agent of wheat leaf rust, to DMI and QoI fungicides. Summa Phytopathologica, v.38, n.4, p.306-311, 2012.

2. Assunção, M.; Torres, A. L. Eficácia versus viabilidade econômica do controle químico e genético da ferrugem da folha em trigo. Ciencia Rural, Santa Maria , v. 43, n. 7, p. 1141-1146, 2013.

3. Barros, B. C; Castro, J. L.; Patricio, F. R. A. Resposta de cultivares de trigo (Triticum aestivum L.) ao controle químico das principais doenças fúngicas da cultura. Summa Phytopathologica, v. 32, n. 3, p. 239-246, 2006.

4. Biotrigo. Cultivares. Passo Fundo. 2012. Available in: <http://www.biotrigo.com.br/cultivares>. Access in: 9 dec. 2015.

5. BRASIL. Ministério da Agricultura Pecuária e Abastecimento. Regras para análise de sementes. Brasília: SNDA/DNDV/CLAV. 398 p. 2009.

6. Campbell, C. L.; Madden, L. V. Introduction to plant disease epidemiology. John Wiley \& Sons, New York, 655 p. 1990.

7. CONAB, C. N. D. A. Séries Históricas, 2015. Available in: <http:// www.conab.gov.br/conteudos.php? $\mathrm{a}=1252 \& \mathrm{t}=2 \&$ Pagina_objcmsconteudos=3\#A_objcmsconteudos $>$ Access in: 20 may 2016.

8. Correa, D.; Nakai, E. H.; De Marco, J. J.; Da Costa, A. C. J. Eficiência de fungicidas no controle de doenças foliares do trigo no Paraná. Acta Iguazu, Cascavel, v. 2, n. 1, p. 20-28, 2013.

9. Cunha, E. A.; Bonaldo, S. M. Eficiência de fungicidas no controle de ferrugem da folha na cultura do trigo. Campo Digital, v. 1, p. 72-78, 2008.

10. Dallagnol, L. J.; Balardin, R. S.; Navarini, L.; Kirinus, E. M. Influência das doenças foliares no rendimento de grãos na cultura do trigo. Revista FZVA, v. 13, p. 139-137, 2006.

11. De Mori, C. Aspectos Econômicos da Produção e Utilização. In: Borem, A., Scheeren, P. L. Trigo: do plantio a colheita. Viçosa: Universidade Federal de Viçosa, 2015. cap. 1, p. $11-34$.

12. EMBRAPA TRIGO. Qualidade comercial do trigo brasileiro: Safra 2006, 2009. Available in: <http://www.cnpt.embrapa.br/biblio/do/p do112 t24. htm $>$ Access in: 20 may 2016.

13. EMBRAPA. Ferrugem da Folha, 2006. Available in: $<$ http://www.cnpt. embrapa.br $>$ Access in: 16 nov. 2015.

14. EMBRAPA: Empresa brasileira de pesquisa agropecuária. Centro Nacional de Pesquisa Agropecuária de Solos (Brasília, DF). Sistema brasileiro de classificação de solos. Brasília: Embrapa Produção de Informação; Brasília, DF: Embrapa Solos, 2013. 154p.

15. Peterson, R. F.; Campbell, A. B.; Hannah, A. E. A diagramatic scale for estimating rust intensity of leaves and stem of cereals. Canadian Journal of Research Section, Ottawa, v. 26, p. 496-500, 1948.

16. Reis, E.M.; Casa, R.T. Doenças dos cereais de inverno - diagnose, epidemiologia e controle. Graphel. 176 p. 2007.

17. Reis, E. M.; Zoldan, S.; Danelli, A. L. D.; Bianchin, V. Ferrugem da folha do trigo - Ciclo da doença. 2009. Available in: <http://www.orsementes. com.br/sistema/anexos/artigos/16/Ciclo $\% 20 \mathrm{da} \% 20$ ferrugem $\% 20 \mathrm{da} \% 20$ folha\%20do\%20trigo.pdf $>$ Access in: 16 nov. 2015.

18. Xue, A. G.; Chi, D. T.; Zhang, S. Z.; Li, Z. S. Wheat Production and Wheat Rust Management in Canada. Journal of Northeast Agricultural University, v. 19, n. 1, 2012. 